УДК 61:007:002.6:681.31

\title{
МЕДИЧНІ ІНФОРМАЦІЙНІ СИСТЕМИ
}

\author{
Комунальний заклад Львівської обласної ради «Львівський обласний центр \\ репродуктивного здоров'я населення» \\ THE MEDICAL INFORMATION SYSTEM \\ M. Y. Malachynska \\ Communal Enterprise of Lviv Regional Council «Lviv Regional Center of Reproductive \\ Health of people»
}

Вступ. Львівський обласний центр репродуктивного здоров'я населення забезпечує різноманітну спеціалізовану, консультативну, діагностичну та лікувальну допомогу.

У комунальному закладі медична інформаційна система «Доктор Елекс» була впроваджена в 2013 році.

3 метою автоматизації технологічного процесу між лікарями та іншими структурними підрозділами було встановлено 16 автоматизованих робочих місць. У результаті з'явилась можливість створити взаємодію між такими структурними підрозділами як: консультативно-лікувальне відділення 3 денним стаціонаром; відділення медико-психологічної допомоги підліткам та молоді «Клініка, дружня до молоді»; лабораторно-діагностичне відділення; реєстратура; кабінет УЗ діагностики. Були автоматизовані ведення профільної медичної карти пацієнта; формування діагностичної гіпотези; ведення подальших повторних візитів, які дають можливість відображати динаміку стану того чи іншого пацієнта. Як наслідок, підвищена якість профілактичної та лікувально-діагностичної роботи, особливо в умовах масового обслуговування при дефіциті часу; суттєво скорочена тривалість прийому; забезпечено швидкий доступ до необхідних документів і бланків.

Висновок. Впровадження інформаційних систем стає невід'ємною частиною професійної діяльності лікарів різних спеціальностей, оскільки дає можливість оптимізувати роботу закладів охорони здоров'я. 